\title{
Lichens and other lithobionts on the carbonate rock surfaces of the heritage site of the tomb of Lazarus (Palestinian territories): diversity, biodeterioration, and control issues in a semi-arid environment
}

\author{
Enrica Matteucci ${ }^{1,2} \cdot$ Arianna Valentina Scarcella $^{2} \cdot$ Paola Croveri $^{2,3} \cdot$ Alessandra Marengo $^{4} \cdot$ Alessandro Borghi $^{4}$. \\ Carla Benelli $^{5} \cdot$ Osama Hamdan $^{6} \cdot$ Sergio Enrico Favero-Longo ${ }^{1}$ (i)
}

Received: 30 November 2018 / Accepted: 13 March 2019/Published online: 18 May 2019

(C) Università degli studi di Milano 2019

\begin{abstract}
Purpose Investigations on the lithobiontic colonization of the stone cultural heritage in (semi-)arid regions are needed to address conservation strategies. In this work, lithobiontic communities were examined on the carbonate rock surfaces of the heritage site of the Tomb of Lazarus. We aimed to evaluate their distribution and interaction with the lithic substrate, together with the efficacy of biocidal treatments for their control.

Methods Diversity and abundance of lithobionts were surveyed on the Jerusalem stone blocks of three architectural elements. Observations at the lichen-rock interface were carried out by reflected light and scanning electron microscopy. The efficacy against lichens of the widely used biocide benzalkonium chloride (BZC) was compared for different concentrations and application methods, and evaluated by epifluorescence microscopy.

Results Chlorolichens were the dominant component of lithobiontic communities, more thoroughly adapted to the semi-arid conditions of the site than mosses and black biofilms of cyanobacteria and dematiaceous fungi. A different structural organization, in terms of thallus thickness and depth of the hyphal penetration component, characterized epilithic and endolithic lichen species, responsible for different deteriogenic activities. Biocidal assays showed that even the methodologies that are usually effective in temperate conditions (as the application of BZC $1.5 \%$ by poultice) may not completely devitalize lichens adapted to the stress conditions of semi-arid climates, unless a pervasive biocide diffusion through metabolically active thalli is carefully guaranteed.

Conclusion Lithobionts act as biodeteriogens on the semi-arid surfaces of the investigated heritage site. Their removal is thus recommendable, but it needs to be adequately supported with a careful calibration of devitalization strategies.
\end{abstract}

Keywords Biocide $\cdot$ Biodiversity $\cdot$ Biofilm $\cdot$ Didactic activities $\cdot$ Lichens $\cdot$ Stone conservation

Sergio Enrico Favero-Longo

sergio.favero@unito.it

1 Dipartimento di Scienze della Vita e Biologia dei Sistemi, University of Turin, Viale Mattioli 25, 10125 Turin, Italy

2 Centro Conservazione e Restauro "La Venaria Reale", Venaria Reale (TO), Italy

3 Dipartimento di Chimica, University of Turin, Turin, Italy

4 Dipartimento di Scienze della Terra, University of Turin, Turin, Italy

5 Associazione pro Terra Sancta (ATS), St. Saviour Convent, Jerusalem, Israel

6 Jericho Mosaic Centre, Jericho, Palestinian Territories

\section{Introduction}

Lithobiontic (micro-)organisms are recognized as biodeterioration agents of the stone Cultural Heritage, causing esthetic damage and often affecting the substrate durability (Tiano 2016). Although biodeterioration phenomena are a worldwide issue, threatening archeological and monumental areas throughout bioclimatic and biogeographical regions, scientific literature on the interactions of lithobionts with the stone substrates, and related control strategies, mostly deal with temperate, Mediterranean, and tropical areas (Caneva and Pacini 2008). In (semi-)arid regions, the diversity of lithobionts has been investigated focusing on their tolerance to harsh 
conditions (Wierzchos et al. 2012), while information on biodeterioration processes and experimental support to address control strategies are generally poor (Caneva and Pacini 2008; Sohrabi et al. 2017).

Lithobionts, including bryophytes, lichens, and biofilms of cyanobacteria, green algae, black yeasts, and/or meristematic fungi, variously affect rock durability (Sterflinger 2010; Albertano 2012; Seaward 2015). In some cases, they physically support disaggregation processes by penetrating the substrate and changing their volume according to water availability (Chen et al. 2000). In other cases, they chemically modify the mineral rock composition by secreting metabolites with acidic and chelating functions, which leach the original mineral constituents and/or promote the neoformation of biominerals (Adamo and Violante 2000; Crispim and Gaylarde 2005; Gadd 2017). On the other hand, a bioprotective role of some lithobiontic communities, acting as a physical barrier (umbrella effect) and biomineralization agents, has sometimes been recognized on certain substrates (Gadd and Dyer 2017). Evaluations of biodeterioration vs. bioprotection are thus far to be generalizable, as patterns and effects of the interaction between lithobionts and lithic substrates may be different for different (micro-)organisms, or even for the same species depending on the colonized lithotype and the (micro-)environmental context (Salvadori and Casanova-Municchia 2016). Similarly, methodologies adopted in restoration work to devitalize lithobionts and support effective cleaning procedures showed different efficacy depending on the target microorganism(s) (e.g., different lichen species, microbial community), but also on the target cultural object, because of some influences of substrate properties and/or weather conditions during treatment and in the days after (Caneva et al. 2008; Barresi et al. 2017; FaveroLongo et al. 2017). Accordingly, policies for the conservation of Cultural Heritage in areas poorly considered by recent advances of scientific research on biodeterioration and its control-as (semi-)arid regions - may benefit from widening in situ investigations to characterize the effective diversity and impact of lithobiontic communities and to calibrate suitable control strategies. Proper choices on the opportunity of removing or preserving lithobiontic communities on heritage surfaces, and of (routinely) adopting a specific methodology for restoration, need indeed to be based on fitting reference investigations, in terms of (micro-)organisms, lithologies, and environmental scenarios (Caneva et al. 2008).

In the case of the carbonate rocks generally named Jerusalem stone, widely used since ancient times in buildings in and around Jerusalem, biodeterioration phenomena on heritage surfaces have been investigated since the 1980s: different weathering patterns were related to present (and past) biodeteriogenic lithobionts and (micro-)climatic conditions (Danin et al. 1982; Danin 1985; Danin and Caneva 1990). Environmental factors driving colonization patterns by epilithic and endolithic lithobionts, together with their adaptation strategies and biogeomorphological effects, have been deeply characterized in the Negev desert (Garty 1999; Kidron and Temina 2008, 2013; Kidron et al. 2016). However, on both natural and heritage surfaces, the attribution of weathering patterns to different lithobionts has been only marginally associated to the microscopical evaluation of their structural organization on and/or within the lithic substrate, which may account for their actual biodeteriorative or bioprotective impact. Moreover, at the best of our knowledge, strategies to control biodeterioration on heritage buildings in (semi-)arid bioclimatic areas still need experimental calibration. In particular, the efficacy of biocide application, variously carried out in temperate and Mediterranean regions to devitalize lithobionts during restoration works (Caneva et al. 2008), should need in situ evaluation against target microorganisms adapted to harsh conditions.

In this work, we investigated lithobiontic communities on the Jerusalem stone blocks of the heritage site of the Lazarus Tomb, located in the east side of Jerusalem's metropolitan area. Lithobiontic communities, responsible for deterioration phenomena worth to be considered in planning and performing conservation activities, were characterized, with a particular focus on lichens. We examined if and how the structural organization of lithobiontic microorganisms and biofilms, and their interaction with the lithic substrate, may account for different weathering patterns. Moreover, we aimed to verify the biocidal efficacy of benzalkonium chloride, a quaternary ammonium salt widely used in restoration work to devitalize biodeteriogens (Caneva et al. 2008), against a dominant lithobiont in the site (the epilithic lichen Variospora aurantia), by using concentrations usually recommended and widely practiced application methods.

This research work was developed as a side activity of an interdisciplinary course on Conservation of Cultural Heritage held at the Lazarus Tomb site, consisting of 14 weekly training modules to provide basic skills about heritage sciences (chemistry, geology, and biology); archeology; as well as practical knowledge dealing with the conservation of stone, wall paintings, and wood. The aim was to introduce a multidisciplinary approach to heritage conservation practice and to develop the critical awareness of young local people, involved with various roles in the ongoing restoration of the heritage site (12 students, both women and men), in relation to the most important conservation issues. The didactic possibility and opportunity of running in situ investigations to directly support teaching on biodeterioration topics in countries still lacking of scientific education in restoration is finally discussed. 


\section{Material and methods}

\section{Study site and lithobiontic diversity survey}

The site of the Tomb of Lazarus (UTM 36R 713635E $3517340 \mathrm{~N} ; 670 \mathrm{~m}$ asl) is located in El-Eizariya municipality (ancient Bethany). The climate is transitional between the hotsummer Mediterranean and arid types (Kottek et al. 2006), with $18{ }^{\circ} \mathrm{C}$ and $264 \mathrm{~mm}$ of mean annual temperature and rainfall, respectively, and approx. $60 \%$ of mean annual air humidity reported for El-Eizariya (ARIJ 2012).

On the side of a steep hill, above the hypogean tomb recognized as that mentioned in the Gospel since at least the fourth century $\mathrm{AD}$, remains of several ancient religious buildings lie between and around the Mosque of al-Uzair (sixteenth century) and the modern Catholic Church of Saint Lazarus (twentieth century) (Caleri 2014; Vella 2017; Fig. 1a). Lithobiontic communities were surveyed in the period October-November 2017 on the architectural elements on which they were cause of esthetic damage. In particular, 20 relevés $50 \times 50 \mathrm{~cm}$ were preferentially distributed, in a number proportional to the commonness of biodeterioration phenomena, on horizontal and vertical surfaces of the Jerusalem stone blocks of: (i) pillars of the superimposed Byzantine and Crusaders' antique churches in the lower "Plaza" ( $n=10$; Fig. 1b) and (ii) walls of the Crusaders' monastery in the upper part of the site $(n=6$; Fig. 1c), uncovered by archeological excavations in 1949-1953, and (iii) the facade of the modern Saint Lazarus church ( $n=4$; Fig. 1b), built in 1952-1955. The Jerusalem stone s.l. is a bio-micritic dolomitic limestone of Cretaceous Age, belonging to the Menhua and Mishash Formations (Avnimelech 1966; Rabinovich et al. 2014). It has been quarried around Jerusalem, hence its name, since the second millennium $\mathrm{BC}$ and constitutes the main building material of the city and its surroundings (Calvo and Regueiro 2010).

Each relevé (plot) was surveyed using a square grid divided into 25 quadrats $(10 \times 10 \mathrm{~cm})$, where the presence of different lithobionts (bryophytes, lichens, cyanobacteria-, and/or black-fungi dominated biofilms) and, in more detail, lichen species was visually estimated. Provisional identificantions during fieldwork were subsequently checked in the laboratory by microscopical observations on small samples of biofilms and lichen thalli, collected by means of micro-invasive techniques. The frequency of lithobionts and lichen species within each plot was calculated as the sum of their occurrences within the grid quadrats (Giordani et al. 2014). Lichen species were identified using Clauzade and Roux (1985) and monographic descriptions. Nomenclature follows Nimis (2016). Sample vouchers were deposited at the Cryptogamic Herbarium of the University of Torino (HB-TO Cryptogamia).

\section{Reflected light and scanning electron microscopy at lichen-rock interface}

Carbonate rock (Jerusalem stone $s . l$.) fragments colonized by lichens, already partially detached from blocks of a wall of the Monastery that underwent rebuilding, were collected with the aid of a lancet and used to investigate lichen-rock interactions. After including fragments in a polyester resin, polished crosssections (approx. 25-40 $\times 10 \times 5 \mathrm{~mm}$ ) were obtained for the epilithic Variospora aurantia (Pers.) Arup, Frödén \& Søchting $(n=3)$ and Verrucaria ochrostoma (Leight.) Trevis. $(n=1)$ and the endolithic Bagliettoa baldensis (A. Massal.) Vězda $(n=1)$ and Pyrenodesmia erodens (Tretiach, Pinna, \& Grube) Søchting, Arup, \& Frödén $(n=1)$. Sections were stained using the periodic acid-Schiff (PAS) to visualize the biological component within the lithic substrate (FaveroLongo et al. 2005). Reflected light microscopy (RLM) observations were carried out using an Olympus SZH10 to measure thallus thickness and the depth of hyphal penetration component (sensu Favero-Longo et al. 2005) of Variospora aurantia, Verrucaria ochrostoma, and B. baldensis. Average values of massive penetration, i.e., depth at which hyphal penetration is continuous beneath the thallus, and maximum penetration, i.e., depth at which hyphal penetration is occasionally observed, were quantified by measuring intervals established at every $800 \mu \mathrm{m}$ from the thallus margin (Favero-Longo et al. 2011).

Polished cross-sections were also observed with a JEOL JSM IT300LV (high vacuum-low vacuum 10/650 Pa; 0.3$30 \mathrm{kV}$ ) scanning electron microscope in back-scattered (BSE) modes (BED-C and BED-S) to visualize the ratio between (bio-)clasts (white to light gray-colored in BSE) and voids including clast boundaries, pores and cracks (porosity s.l., black-colored in BSE) (Sardini et al. 2006; Favero-Longo et al. 2009; Morando et al. 2017). On two cross-sections, BED-C images were acquired (at $\times 150$ magnification) of a $300-\mu \mathrm{m}$ layer beneath the surface showing the epilithic Variospora aurantia, the endolithic $P$. erodens, and absence of lichens (section 1); a 300- $\mu$ m layer beneath the surface showing the endolithic $B$. baldensis and absence of lichens (section 2); 300- $\mu \mathrm{m}$ layers at more than $2 \mathrm{~mm}$ from the surface (sections 1 and 2). BED-C images of sectioned fresh fragments $(n=2)$ sampled from the interior of blocks were also acquired as control. Images (at least three per each different case study) were processed by a pixel-based gray scale classification using the software WinCAM Pro 2007d (Regent's Instrument, Canada) to quantify total percentage porosity s.l. BED-S images on the same areas were examined to characterize hyphal penetration patterns with respect to the rock microstructure.

The cross-sections were prepared in the Laboratory of Lichenology (ISO 9001:2015) and are conserved in the Lichen-Petrographic Collection of the Herbarium of the 
Fig. 1 The site of the Tomb of Lazarus. a Walls of the crusaders' monastery in the foreground, and view of Mosque of al-Uzair (left) and the modern Church of Saint Lazarus (right) in the background. b Lower "Plaza," with the pillars of the Byzantine and Crusaders' antique churches in the foreground, and the façade of the modern church in the left background. c Walls of the Crusaders' Monastery, with carved capitals in the foreground. d Lithobiontic community including chlorolichens, bryophytes, and a black cyanobacterial biofilm on blocks of the pillars of the antique church. e Upper surface of a carved capital of the Crusaders' Monastery, covered by lichens (mostly orange thalli of Variospora aurantia) partially hidden by dust deposits, but made visible by wetting their thalli (left side). f Black fungi, in part overgrowing chlorolichens, on the façade of the modern church (the $50 \times 50 \mathrm{~cm}$ square grid used for relevés is visible on the vertical surface)
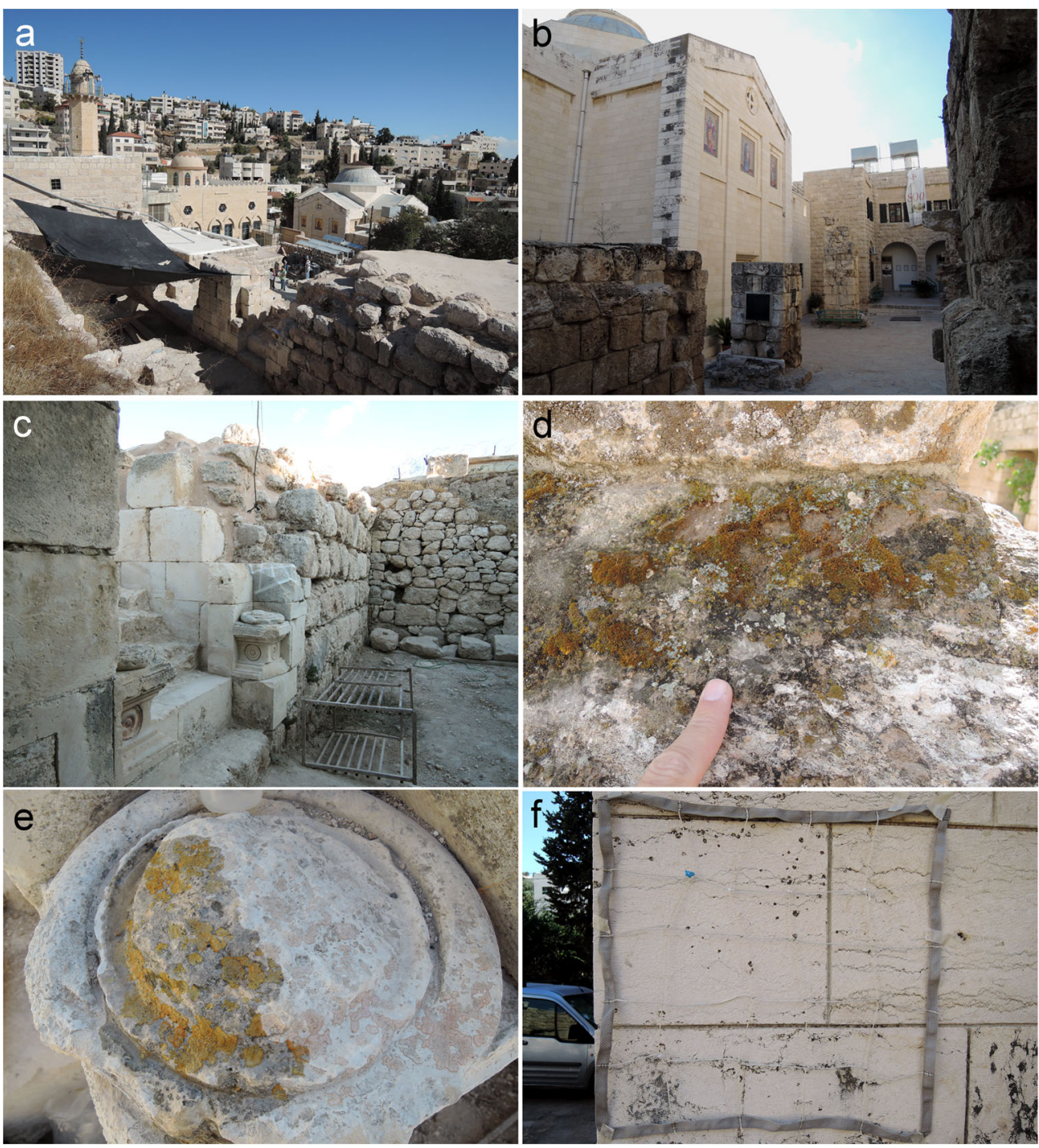

University of Torino (Gazzano et al. 2007). Petrographic thin sections, prepared from the fresh fragments of the interior of rock blocks and used for a petrographic analysis of the lithotype, are conserved in the Rocks and Thin Sections Collection of the Earth Science Department of the University of Torino.

\section{Biocide assays}

Biocide assays were performed, with commercial products available on site, on two distinct carbonate rock surfaces (block-1, block-2) colonized by Variospora aurantia and, subordinately, other lichen species. The epilithic, crustose-placodiomorph Variospora aurantia was chosen as target species because of its extreme commonness on natural and man-made lithic surfaces in urban and rural areas of the middle East, due to its tolerance to harsh environmental conditions, including air pollution (Garty 1999), and because of the possibility of sampling its thalli more easily than those of other epilithic crustose and endolithic lichens.
The commercial product BAC50 (distributed by Monum, Jerusalem), a water solution of benzalkonium chloride (BZC $50 \% \mathrm{v} / \mathrm{v}$ ), was applied at two different final concentrations of the active substance (BZC $0.25 \%$ and 1.5\%), the highest one defined according to manufacturers' instructions for analogous products (e.g., BAC50 distributed by Sinopia, Torino, Italy). Tap water was used for dilutions and for control assays, as it was the water available in the restoration yard. On block-1, after having pre-wetted the rock surface and the thalli with sprayed tap water, the biocide was applied on distinct plots (approx. $10 \times 10 \mathrm{~cm}$ ), (i) using a paint brush and (ii) with a cellulose-sepiolite poultice applied on Japanese paper. The treated plots were kept covered for $3 \mathrm{~h}$ with aluminum foils. Thereafter, the poultice was gently removed and all the treated surfaces were rinsed with water and a nylon brush. On block-2, after having moistened the rock surface and the thalli with sprayed tap water, the biocide was applied on distinct plots, using (i) a paint brush and (ii) a nebulizer. The plots were not kept covered after the treatment and, after $3 \mathrm{~h}$, were rinsed with tap water or left unrinsed. 
Fragments of Variospora aurantia thalli were collected from plots on blocks- 1 and -2 , at the end of the biocide treatment and after 40 days, to compare the biocide effects when applied by brush vs. with poultice and on rinsed vs. unrinsed plots, at a short and long term. The sampled thalline fragments were conserved in Falcon tubes for $48 \mathrm{~h}$ and then hand-made cross sectioned to carry out epifluorescence observations under a Nikon Eclipse 300 microscope. Quality and quantity of the fluorescence emitted by photobiont cells, spatially informative on the vitality of the photobiont layer (e.g., Tretiach et al. 2012), were evaluated, and the data interpreted using an ordinal scale on the relative abundance of viable (red colored) and devitalized (appearing white) cells (Favero-Longo et al. 2017).

\section{Results}

\section{Abundance and distribution of lithobiontic communities}

The field survey and subsequent microscopical observations indicated chlorolichens, bryophytes, and black biofilms of different compositions as biodeteriogens responsible for phenomena of esthetic damage in the site of the Tomb of Lazarus (Figs. 1d-f and 2). On the carbonate rock blocks of the antique churches and the monastery, chlorolichens were the dominant component in terms of both frequency per plot (median $>90 \%$ of quadrats) and surface cover (median $>20 \%$ ). Black biofilms and, subordinately, bryophytes were common on the pillars of the antique churches, on which they were responsible for remarkable covers (av. > 10\%), while their presence was rather negligible on the monastery walls. On the walls of the modern church, chlorolichens and black biofilms displayed high frequency values (av. $>30 \%$ ), but remarkable covers only sparsely occurred (median $<5 \%$ ) and were mostly located in the upper parts of the façade (Fig. 1b), not accessed for the relevés.

A total of 17 chlorolichen taxa were listed in the site, most of which displayed crustose epilithic $(65 \%)$ and crustose endolithic (24\%) growth form (Table 1). A similar number of species was detected on walls of the antique churches $(n=14)$

Fig. 2 Frequency (av. \% per plot, a) and cover $(\%, \mathbf{b})$ of lithobionts (lichens, white columns; black biofilm, dark gray columns; bryophytes, light gray columns) on the investigated architectural elements in the site of the Tomb of Lazarus. Maximum (upper whisker), 75th percentile (top box), mean (square), median (transversal line), 25th percentile (bottom box), minimum (lower whisker) and the monastery $(n=13)$, while only few species $(n=6)$ characterized the façade of the modern church. The crustose endolithic Verrucaria ochrostoma and the crustose placodiomorph Variospora aurantia were the most widespread species through the overall surveyed quadrats (frequency of $33 \%$ and $24 \%$, respectively), and determined remarkable covers on the surfaces of both the antique churches and the monastery ( $\max$. values $>10 \%$ ). The endolithic B. baldensis and the epilithic Lepraria sp. were also locally responsible for remarkable covers $(20 \%)$ on the walls of the antique churches, while other species, even when characterized by high-frequency values, never displayed cover values $\geq 20 \%$.

Coccoid and, rarely, filamentous cyanobacteria, together with black yeasts and meristematic fungi, were the main components of the black biofilms, which developed directly on the carbonate substrate and-more often - on senescent thalli of chlorolichens (Fig. 3). Black fungi were particularly abundant on the walls of the modern church, while their detection on the antique church and Monastery blocks was sporadic.

\section{Lichen interactions with the carbonate rocks}

RLM observations at the lichen-substrate interface showed a different structural organization of the epilithic V. aurantia and endolithic species (Fig. 4). The former displayed a thicker thalline component (av. $0.2 \mathrm{~mm}$ ), but its hyphal penetration component (HPC sensu Favero-Longo et al. 2005) was scarce, characterized by an av. depth of massive penetration of $0.03 \mathrm{~mm}$ and av. values of maximum penetration of $0.2 \mathrm{~mm}$ (Fig. 4b, c, f). In some cases, local staining of biological structures within the substrate beneath the $V$. aurantia thalli corresponded to free colonies of dematiaceous fungi, already observed for their colored appearance before the PAS treatment, and not to mycobiont penetrating hyphae (Fig. 4a). By contrast, only a thin lithocortex and discontinuous thalline structures (av. thickness $\leq 0.1 \mathrm{~mm}$ ) were visible on surfaces colonized by the endolithic B. baldensis and $V$. ochrostoma, respectively. Both the species showed a remarkable hyphal penetration component, massively penetrating the substrate

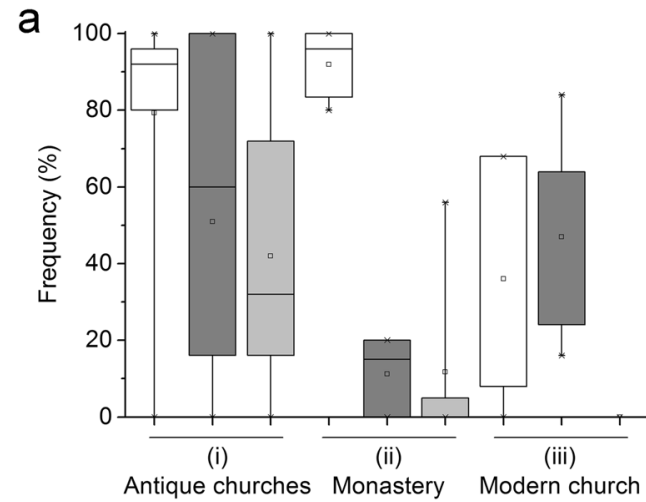

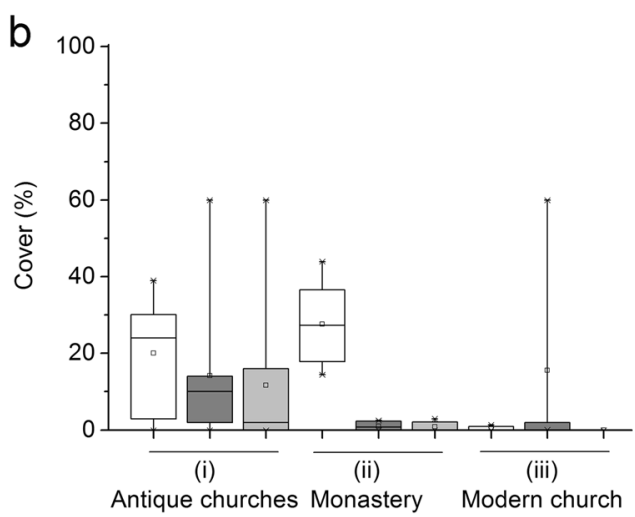


Fig. 4 Interface between lichens and the Jerusalem stone (cross sections observed by RLM). a Free colonies of dematiaceous fungi (\#) beneath a thallus of Variospora aurantia. b-e Hyphal penetration component of epilithic and endolithic lichens (cross-sections stained by PAS, visualizing biological structures in violet): b Variospora aurantia (*, hyphal penetration limited to a crack); c Pyrenodesmia erodens (left) and V. aurantia (right); d Bagliettoa baldensis (§, perithecia); e Verrucaria ochrostoma (§, perithecia). Scale bars $=0.5 \mathrm{~mm}$ (a, c, e), $1 \mathrm{~mm}(\mathbf{b}, \mathbf{d})$. f Quantitative characterization of the specific structural organization (av. thallus thickness, massive and maximum depth of hyphal penetration component). For each parameter, columns which do not share letters are significantly different (ANOVA, Tukey's test, $p<0.05$ )
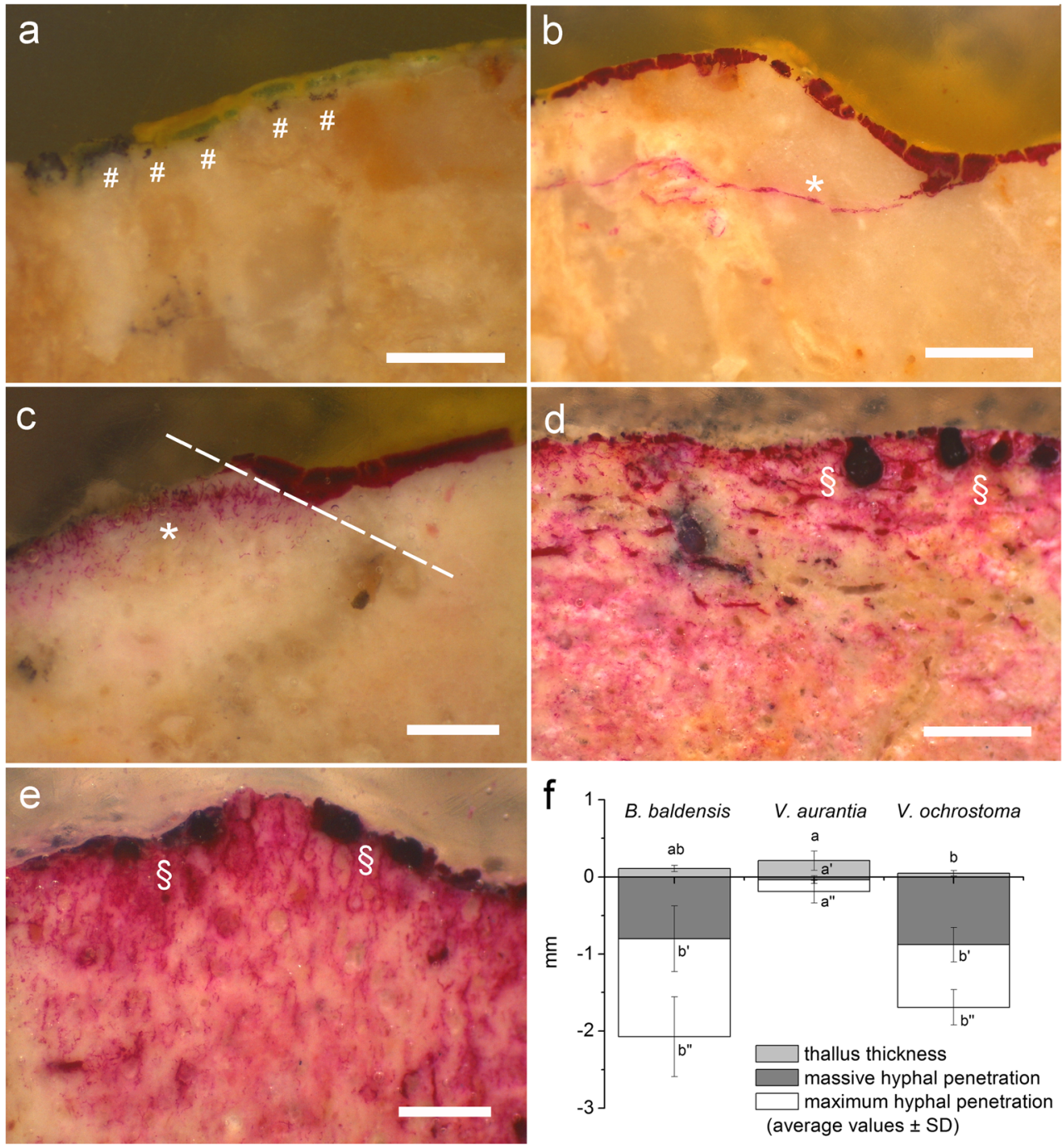

down to av. depths of $0.8 \mathrm{~mm}$ and with maximum penetration av. values of 2.1 and $1.7 \mathrm{~mm}$, respectively (Fig. 4d, e). Moreover, their perithecia endolithically developed down to $0.3-0.4 \mathrm{~mm}$, their growth appearing the potential responsible for pitting phenomena sparsely observed on the carbonate blocks through the site. Massive hyphal growth through the carbonate matrix, rather than limited to intragranular porosities or rock fractures (as sometimes observed for $V$. aurantia) characterized both endolithic species. It is worth noting that strong penetration of endolithic thalli (like those of Pyrenodesmia erodens in Fig. 4c) growing adjacently to $V$. aurantia, which shows negligible hyphal penetration component, indicates that the different species, rather than variations in substrate properties, are responsible for the heterogeneous structural organizations of the different taxa above and beneath the rock surface.

SEM-BSE observations of the petrographic thin sections showed the bioclastic structure of the Jerusalem stone and a remarkable porosity internal to bioclasts (Fig. 5a). The polished cross-sections of the same fresh fragments highlighted that the microfossils are tightly embedded within a fine-grained calcite matrix (Fig. 5f). The massive hyphal penetration by endolithic lichens affects the total porosity of the upper rock layers (Fig. 5b). The 300- $\mu \mathrm{m}$ layer penetrated by P. erodens (Fig. 5e) and B. baldensis (Fig. $5 \mathrm{~g}$, h) beneath the rock surface showed significantly higher values of total porosity than those covered by V. aurantia (Fig. 5d) or not colonized by lichen thalli (Fig. 5c). Such endolithic effect was observed on both section 1, which in absence of $P$. erodens showed a low total porosity similar to control sections, and section 2 , showing a total porosity higher than control sections even at depths lower than $2 \mathrm{~mm}$ from the surface. BED-S observations confirmed the hyphal penetration through the rock matrix (Fig. 5g) and showed the hyphal invasion of the bioclast internal porosity (Fig. $5 \mathrm{~h}$ ).

\section{Biocide efficacy}

Fluorescence microscopy showed that any but one of the assayed biocide treatments significantly affected the vitality 


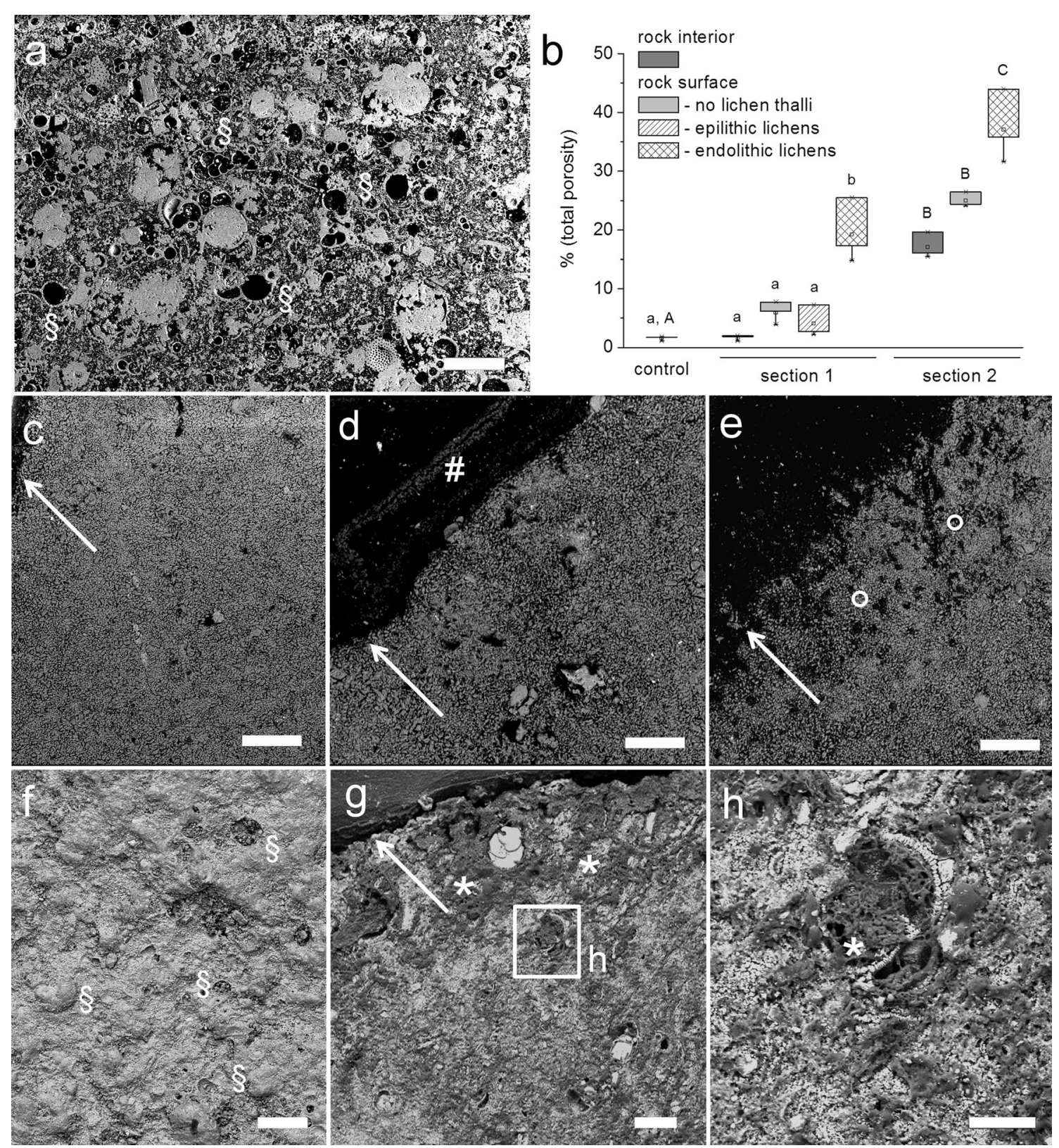

Fig. 5 Lichen effect on the total porosity of the Jerusalem stone (sections observed by SEM-BSE). a Petrographic thin section of a fresh fragment, showing porosity internal to bioclasts (§). b Quantitative characterization, based on image analysis, of the total porosity of a 300- $\mu$ m layer beneath the surface showing the epilithic Variospora aurantia, the endolithic Pyrenodesmia erodens, and absence of lichens (polished cross section 1 ); a 300- $\mu \mathrm{m}$ layer beneath the surface showing the endolithic Bagliettoa baldensis and absence of lichens (section 2); 300- $\mu$ m layers

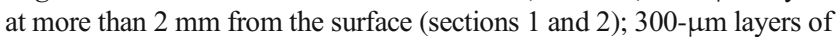
fresh fragments as control. For each section, columns which do not share

of $V$. aurantia. In thalline fragments collected from block-1 at the end of the biocide treatments, the photobionts of thalli exposed to $0.25 \%$ and $1.5 \%$ BZC applied by brush or to $0.25 \%$ BZC applied with poultice still widely preserved their chlorophyll integrity (indicated by the red photobiont fluorescence), particularly in the lower part of the algal layer letters are significantly different (ANOVA, Tukey's test, $p<0.05$ ). c-e BED-C images of section 1: c rock surface (arrow) not colonized by lichen thalli; $\mathbf{d}$ rock surface (arrow) covered by a $V$. aurantia thallus (\#); e rock surface (arrow) dissolved by $P$. erodens $\left({ }^{\circ}\right.$ ). f BED-S image of a polished cross sectioned fresh fragment, with bioclasts $(\S)$ embedded in a fine-grained calcite matrix. $\mathbf{g}-\mathbf{h}$ BED-S images of section 2: $\mathbf{g}$ rock surface (arrow) penetrated by B. baldensis (*), with hyphae invading the internal porosity of bioclasts (magnification, h). Scale bars $=100 \mu \mathrm{m}$ (a, $\mathbf{c}-\mathbf{g}), 25 \mu \mathrm{m}(\mathbf{h})$

(Fig. 6b). Only the $1.5 \%$ BZC applied with poultice remarkably killed most of the treated thalli: a residual occurrence of viable photobiont cells was only rarely observed in the lower part of the algal layer in few of the thalline fragments (Fig. 6a). Nevertheless, also this treatment failed to devitalize the whole photobiont populations in all thalli and some recovery of 
Fig. 6 Epifluorescence observations run on hand cut transverse sections of thalli of Variospora aurantia upon biocide treatments. a, b Samples collected from block- 1 at the end of the application of $1.5 \%$ BZC by cellulose-sepiolite poultice (a) and $0.25 \%$ BZC by brush (b). c, d Samples collected at the end of the application of BZC $1.5 \%$ by nebulizer, without rinsing (c), and after 40 days $(\mathbf{d})$. Scale bars $=$ $40 \mu \mathrm{m}$
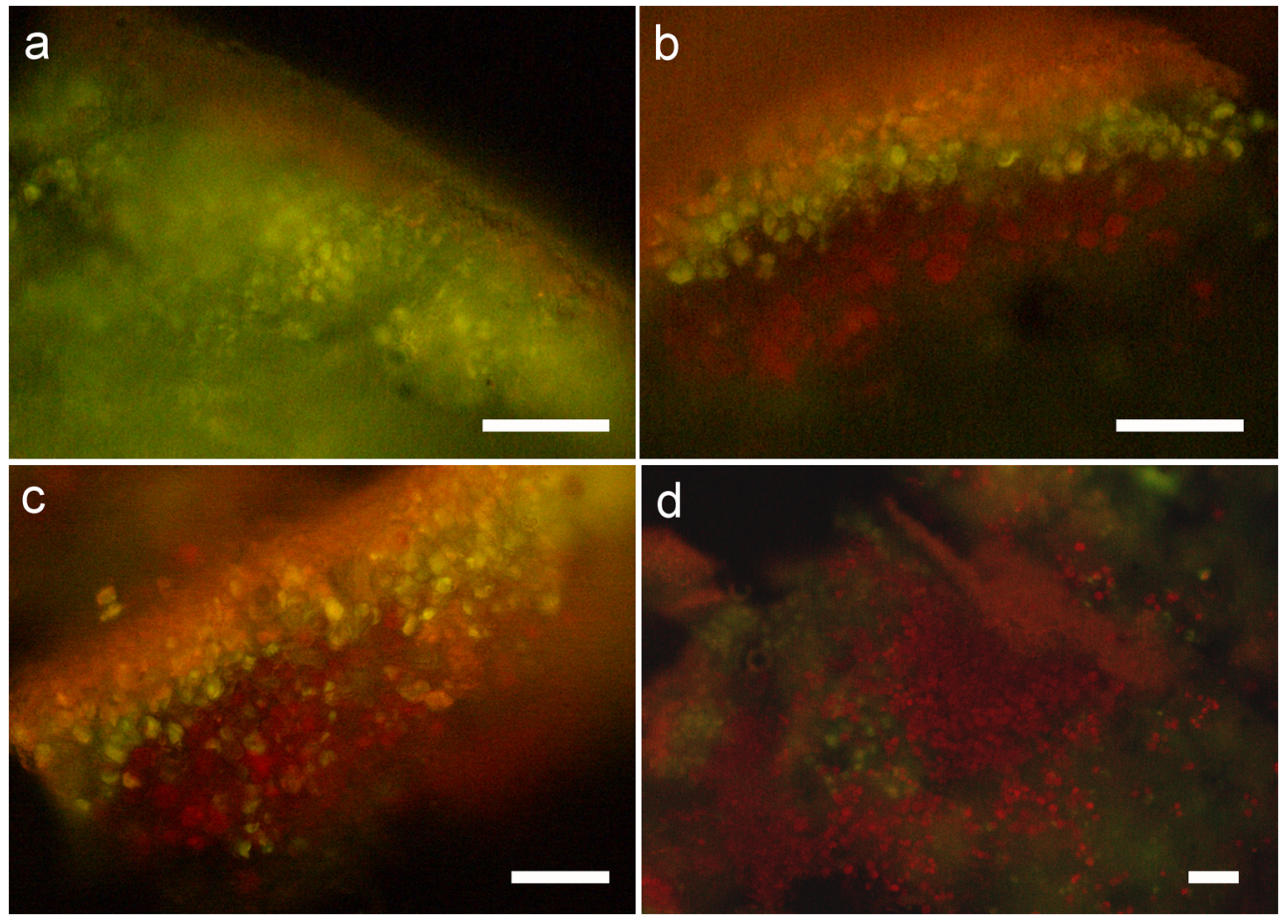

d viability was observed after 40 days. On block-2, neither the rinsed nor the non-rinsed thalli treated with BZC $0.25 \%$ and $1.5 \%$, by brush or nebulizer, displayed the devitalization of the whole photobiont layer, with wide amounts of viable cells persisting in its lower part (Fig. 6c). Moreover, a remarkable recovery of viability was observed after 40 days, with many viable cells appearing through the photobiont layer (Fig. 6d).

\section{Discussion}

\section{Biodiversity of lithobionts}

Cyanobacteria, black fungi, and/or lichens were indicated as specialized biodeteriogenic microorganisms on archeological and monumental surfaces in (semi-)arid areas of the Mediterranean basin, mostly because of their high resistance to desiccation and high solar irradiation (Warscheid 2003; Mihajlovski et al. 2015). However, a low number of studies is so far available on biodeterioration of cultural heritage in semi-arid regions (Caneva and Pacini 2008; Sohrabi et al. 2017), and they poorly considered interactions between lithobionts and their substrate, and potential control strategies. In the heritage site of the Tomb of Lazarus, we found chlorolichens as the dominant component of lithobiontic communities on the surveyed architectural elements, where cyanobacteria and black fungi were instead only locally abundant. Such subordinate occurrence of cyanobacteria and the absence of cyanolichens, reported as dominant lithobiontic components on the walls of historic buildings in Jerusalem, at few kilometers and on the same carbonate substrate (Danin and Caneva 1990), likely follows the strong aridity gradient from the center of the metropolitan area of Jerusalem (500$600 \mathrm{~mm}$ of annual rainfall) to the eastern suburbs, including El-Eizariya $(<300 \mathrm{~mm})$. Although cyanobacteria and cyanolichens may longer retain water by their gelatinous sheats, chlorolichens can better adapt to the scarcity of liquid water and the availability of humid air typical of (semi-)arid areas (e.g., 60\% mean annual air humidity in El-Eizariya; ARIJ 2012), as their photobionts are able to photosynthesize in the partially hydrated state (Honegger 2012). Regional climate variability is thus the primary factor to drive lithobiontic diversity and different deterioration threats (Caneva and Pacini 2008).

Differences in the relative abundance of lithobiontic components on the surveyed architectural elements highlight the parallel remarkable role of local topography and building geometry to determine micro-environmental conditions and shape different micro-niches at the scale of a single heritage site (Nimis et al. 1998; Tonon et al. 2019). Similarly, the distribution pattern of lichen species is characterized by higher species turnover (beta-diversity) between than within each architectural element (SDR analysis, following Podani and Schmera 2011, not shown). High frequency and cover by coccoid cyanobacterial biofilms only characterized the pillars of the antique churches, located in the lower and windsheltered part of the site, where the co-presence of abundant bryophyte mats also indicates the periodical availability of liquid water, necessary for their photosynthetic activity and survival (Lakatos 2011). By contrast, chlorolichens are also 
adapted to the more xeric conditions of the walls of the monastery, located in the wind-exposed upper part of the site, where rock surfaces are widely covered by dust (Fig. 1e). It is worth noting that nitrophytic lichen species, tolerant of (and even favored by) nitrogen deposition, including ammonia pollution, prevail throughout the site ( 9 out of the 17 species have maximum eutrophication index $\geq 4$; Table 1 ), as generally reported for monuments in urban (Aptroot and James 2002; Seaward 2015) and agricultural areas (Nascimbene and Salvadori 2008; Sohrabi et al. 2017). Both the dominant species Variospora aurantia and Verrucaria ochrostoma are nitrophytic species (Nimis 2016). The former, displaying highest frequency and cover values on the monastery walls, was previously reported as highly tolerant to harsh conditions of sun irradiation, aridity, and air pollution (Garty 1999). Only the nitrophytic Calogaya pusilla determined remarkable lichen covers on the walls of the modern church, made of the same lithotype, but characterized by a poor colonization with respect to the surrounding antique surfaces. Abiotic and biotic weathering forces may have not so far modified the scarce intrinsic bioreceptivity of the strong and durable Jerusalem stone (Ghadban and Ashhab 2011) towards a remarkable secondary (i.e., weathering induced) bioreceptivity (Guillitte 1995; Miller et al. 2009). A prominent occurrence of species of Caloplaca s.l. ( 6 out of the 17 species in the investigated site) also characterized carbonate surfaces of the Pasargadae UNESCO world heritage site (Iran), where frequent events of windstorms contribute to nitrogen and dust deposition (Sohrabi et al. 2017). In such species, adapted to alkaline substrates (Ariño et al. 1995), a role of dust deposits on the thalline surface in protecting photobionts by excessive sun irradiation, together with biosynthetized calcium oxalate and parietin deposits (Smith et al. 2009) may be worth to be considered.

\section{Biodeterioration}

The endolithic growth, characterizing Verrucaria ochrostoma and other species in the site, represents a strategy to protect photobionts from harsh environmental conditions in hot and cold arid environments (Wierzchos et al. 2012). Physiology and environmental adaptation of euendolithic (i.e., actively boring) lichens in (semi-)arid environments has been widely investigated on natural outcrops (Kidron et al. 2016). Such adaptive pattern has consequences in terms of biodeteriorative effects, as widely documented by pitting phenomena on carbonate rocks of (semi)-arid natural environments (Danin 1992; Bungartz and Garvie 2004; Kidron and Temina 2008), but also, remarkably, on monuments of temperate and Mediterranean areas (Salvadori and Casanova-Municchia 2016; Pinheiro et al. 2018). Endolithic lichens also characterized the Pasargadae Iranian site (Sohrabi et al. 2017), but the presence of discocarpous rather than pyrenocarpous species determined the absence of remarkable biopitting phenomena (Pinna et al. 1998). On the contrary, such pitting phenomena characterize the investigated site, where both the pyrenocarpous $V$. ochrostoma and B. baldensis, producing large perithecia, widely occur on and penetrate the carbonate rock blocks, determining physical and chemical deterioration processes. Owing to conservative reasons, microscopy observations were limited to one single cross-sectioned fragment for each endolithic species. Nevertheless, it is worth noting that the depths of massive and maximum hyphal penetration (approx. 1 and $2 \mathrm{~mm}$, respectively) were the same quantified for $B$. baldensis in fine-grained limestones from the temperate N-Italy (Favero-Longo et al. 2009). The pattern of endolithic growth within a certain substrate thus appears as a functional trait poorly influenced by the climate context. On the other hand, as previously observed for the epilithic Calogaya biatorina (A. Massal.) Arup, Fröden, \& Søtching in Pasargadae (Sohrabi et al. 2017), V. aurantia did not show a conspicuous hyphal penetration, which seems to exclude mechanical disaggregation activity or active substrate dissolution. Accordingly, no weathering patterns were observed in (semi-)arid environments on the surface of cobbles colonized by other epilithic species of Caloplaca s.l., and a potential bioprotective role was even suggested (Kidron et al. 2016). Our SEM-BSE observations, characterizing the lichen effect on porosity, i.e., a physical property relevant for surface durability, did not show bioprotection by Variospora aurantia, but a remarkable deterioration impact by endolithic lichens. In particular, hyphal penetration seems to promote the connection between the surface and the internal porosity of bioclasts, finally threatening the endolithically colonized rock volumes more than the others.

Moreover, the observed occurrence of additional lithobionts at the thallus-rock interface, in particular beneath $V$. aurantia, confirms a role of lichens in creating suitable microhabitats for the colonization of rock substrata and thus supporting biodeterioration dynamics (de los Ríos et al. 2009). The abundance of senescent thalli intermingled in the black cyanobacterial and fungal biofilms also suggests a role of lichens in promoting the lithobiontic colonization on the rock surfaces in semi-arid environments. In this sense, both endolithic and epilithic lichen species behave as biodeterioration agents on carbonate stone materials in semi-arid environments, physically and chemically affecting the durability of their surface layers, at a millimeter scale, and/or determining surface esthetic damage with the growth of the thalline component and/or favoring a lithobiontic succession. Biodeterioration processes particularly threaten the surface stone conservation in the case of the antique architectural elements, more colonized by lichens and already exposed to a long history of abiotic and biotic weathering forces. Poor lichen colonization on the approx. 60 years old surface of the modern church, mostly due to epilithic species of Caloplaca 
s.l., suggests that very long times (likely centuries) may be necessary before fresh surfaces of the Jerusalem stone significantly suffer lichen-driven physical disaggregation or chemical leaching, while the esthetic damage is a more immediate concern. However, the contribution by endolithic lichens in increasing open porosity may likely speed up the process.

\section{Control of biodeteriogens}

Findings about biodeterioration activity support the opportunity of removing lichens and other lithobionts from heritage surfaces in semi-arid environments. In this context, the preliminary devitalization of lithobionts is a crucial step, as the residual occurrence of viable cells on the cleaned surface or their dispersion during the mechanical removal of biofilms and thalli may be a source for a short-term reoccurring of colonization (Jurado et al. 2014; Pinna 2017). The necessity of species- and site-specific calibrations to assess the efficacy of biocide treatments against lichens has been recently experimentally remarked (FaveroLongo et al. 2017). The assays carried out in the site of the Tomb of Lazarus indicate that a single treatment with BZC, used in a low $(0.25 \%)$ but also in the maximum (1.5\%) concentration recommended for a series of BZC commercial products of analogous formulation, applied by brush or with poultice, does not guarantee a good efficacy in the devitalization of Variospora aurantia. A scarce efficacy of brush applications, already reported for several biocide products (Favero-Longo et al. 2017) was here further confirmed. The general efficacy previously documented for poultice applications and correlated to an increased contact time between biocide and the hydrated thalli (FaveroLongo et al. 2017) was not recorded in this case. Hydration of thalli is a crucial step for the efficacy of the biocide treatments, as lichens and the other poikilohydric lithobionts (i.e., organisms with the water status depending on the environment) are strongly stress-tolerant when dry, but sensitive when wet and metabolically active (Tretiach et al. 2012; Pinna 2017). The layering of killed and viable cells in the upper and lower parts of the photobiont layer, respectively, suggests that (i) pre-wetting of the rock surfaces and thalli with sprayed water; (ii) brush, nebulizer, and even poultice applications of biocide; and (iii) the final rinsing step were not sufficient to hydrate the thalli and allow the biocide penetration. The efficacy of the adopted BZC at $1.5 \%$ of concentration on the target organism is indicated by the successful devitalization of part of the photobiont layer (despite the use of tap water and the abundance of carbonate deposits on the thallus surface), while the critical crux seems related to the biocide diffusion. Biocide applications were performed in a cloudy day (temperature at midday approx. $30^{\circ} \mathrm{C}$ ) and, in the case of the poultice application, the thalline surfaces, covered with aluminum foils, still appeared humid at poultice removal. The reached level of hydration, however, did not likely allow the metabolic activation of the whole photobiont layer, and its lower part was locally unaffected. Similarly, in the case of block-2, hydration of thalli by environmental humidity during the weeks following the treatment was not sufficient to increase the biocidal effect and recovery signals were even observed after 40 days. Such resilience to biocide treatments confirms the wide-spectrum stress tolerance reported for Variospora aurantia (Garty 1999) and indicates, in particular for lichens adapted to (semi-)arid climates, the need of carefully evaluating what application method may provide a pervasive diffusion of biocides through metabolically active thalli. In this sense, results by brush and nebulizer applications could be hardly improved, while modulation of the duration of poultice applications and the possibility of repeated poultice hydration may possibly make the treatment effective. On the other hand, the adoption of devitalization techniques alternative to biocide applications is generally recommended to limit the spread of toxic compounds (Pinna 2017). Difficulties encountered in biocide treatments make the heat shock treatments of lithobionts (Tretiach et al. 2012) particularly worth of consideration to control biodeterioration in semi-arid environments, taking advantage of — rather than suffering — hot climate conditions.

\section{Didactic value of in situ investigations}

A new scientific and critical concept of conservation, based on a multidisciplinary approach involving scientific, historical, and artistic knowledge, was early promoted in Italy, since the end of the 1930s, by Argan (1938) and Brandi (1963), contributing to the development of the profession of scientific conservator-restorer. Knowledge in human and natural sciences, combined with a strong awareness in conservation issues, practical intervention techniques, and skills in planning activities and studies specifically tailored on artwork needs, acquired through specific educational pathways, is now required to be qualified as professional conservators and restorers in several countries (e.g., in Italy; MiBACT 2014). In some areas of the world, however, such kind of professional training can be hardly accessed, and it is difficult to involve in restoration projects experts which are scientifically aware of all the conservation issues.

In the site of the Tomb of Lazarus, theoretical and practical activities dealing with biology applied to cultural heritage $(n=2$ weekly modules) made the students - including those having a coordinative and an operative role in the restoration workaware of the occurrence of lithobionts (previously generally perceived as "dirt") and of their potential role in stone biodeterioration. Moreover, the students were taught about the necessity of devitalizing biodeteriogens before their mechanical removal, which may otherwise risk of scattering rather than control their occurrence, as experienced in other restoration projects documented for the (semi-)arid regions (Sohrabi et al. 2017). Such take-home messages is an essential part of the stock of knowledge that everyone working in conservation of the stone cultural heritage throughout the world should have. 


\section{Conclusions}

In conclusion, lithobiontic communities colonize antique and modern carbonate rock surfaces in the heritage site of the Tomb of Lazarus. Epilithic and endolithic chlorolichens result more thoroughly adapted to the semi-arid climate conditions of the site, while bryophytes and biofilms of cyanobacteria and black fungi only characterize wind-sheltered architectural elements. Both endolithic and epilithic lichens are agents of biodeterioration, by physically and chemically affecting the rock surface, causing esthetic damage or supporting lithobiontic succession. Their removal is thus recommendable, particularly for the antique surfaces already affected by long-term exposure to biotic and abiotic weathering factors. However, the preliminary devitalization practices, necessary for an effective restoration intervention, may encounter remarkable tolerance and resilience. Indeed, even the application by poultice of the widely used biocide BZC, usually effective against lithobionts in temperate conditions, may be ineffective to devitalize lichens adapted to the stress conditions of semi-arid climates. If the adopted application method does not guarantee a pervasive biocide diffusion through a metabolically active thallus, the efficacy of the treatment is incomplete and mechanical cleaning operations risk to scatter, rather than control, the lithobiontic colonization.

Acknowledgements The authors are grateful to the students attending the training school, all the people working for the conservation of the site of the Tomb of Lazarus, Najati Fitiani for the precious interpreter work, Sara Aveni for the English revision, and all colleagues of ATS Terra Sancta, Centro Conservazione e Restauro "La Venaria Reale," Jericho Mosaic Center, Municipality of Torino and University of Torino, participating in the project.

Funding Investigations were carried out in the framework of the international cooperation Palestinian Municipality Support Program EJE CH096 17, financially supported by Italian Ministry of Foreign Affairs.

\section{Compliance with ethical standards}

Conflict of interest The authors declare that they have no conflict of interest.

Research involving human participants N/A

Informed consent N/A

\section{References}

Adamo P, Violante P (2000) Weathering of rocks and neogenesis of minerals associated with lichen activity. Appl Clay Sci 16:229-256

Albertano P (2012) Cyanobacterial biofilms in monuments and caves. In: Whitton BA (ed) Ecology of cyanobacteria II. Springer, Dordrecht, pp 317-343
Aptroot A, James PW (2002) Monitoring lichens on monuments. In: Nimis PL, Scheidegger C, Wolseley P (eds) Monitoring with lichens-monitoring lichens. Springer, Dordrecht, pp 239-253

Argan GC (1938) Restauro delle opere d'arte. Progettata istituzione di un Gabinetto Centrale del Restauro. In: Il Convegno dei Soprintendenti, Bollettino d'arte, pp 133-137

ARIJ - The Applied Research Institute - Jerusalem (2012) El 'Eizariya (including Al Ka'abina) Town Profile. Accessed on line at: http:// vprofile.arij.org/jerusalem/pdfs/vprofile/E1\%20Eizariya_EN.pdf. Accessed 22 Nov 2018

Ariño X, Ortega-Calvo JJ, Gomez-Bolea A, Sáiz-Jiménez C (1995) Lichen colonization of the Roman pavement at Baelo Claudia (Cadiz, Spain): biodeterioration vs. bioprotection. Sci Total Environ 167:353-363

Arup U, Søchting U, Frödén P (2013) A new taxonomy of the family Teloschistaceae. Nordic J Bot 31:016-083

Avnimelech M (1966) Influence of geological conditions on the development of Jerusalem. Bull Am Schools Orient Res 181:24-31

Barresi G, Cammarata M, Palla F (2017) Biocide. In: Palla F, Barresi G (eds) Biotechnology and conservation of cultural heritage. Springer, Cham, pp 49-65

Brandi C (1963) Teoria del Restauro. Editori di Storia e Letteratura, Roma

Bungartz F, Garvie LA (2004) Anatomy of the endolithic Sonoran Desert lichen Verrucaria rubrocincta Breuss: implications for biodeterioration and biomineralization. Lichenologist 36:55-73

Caleri A (2014) La prima chiesa di Betania: nuove proposte interpretative. In: Temporis Signa. Archeologia della tarda antichità e del medioevo 9. CISAM, Spoleto, pp 181-194

Calvo JP, Regueiro M (2010) Carbonate rocks in the Mediterranean region-from classical to innovative uses of building stone. In: Smith BJ, Gomez-Heras M, Viles HA, Cassar J (eds) Limestone in the built environment: present-day challenges for the preservation of the past. Geol Soc Lond, Spec Publ 331:27-35

Caneva G, Pacini A (2008) Biodeterioration problems in relation to geographycal and climatic contexts. In: Caneva G, Nugari MP, Nugari MP, Salvadori O (eds) Plant biology for cultural heritage: biodeterioration and conservation. Getty Publications, Los Angeles, pp 219-237

Caneva G, Nugari MP, Salvadori S (2008) Control of biodeterioration and bioremediation techniques. In: Caneva G, Nugari MP, Salvadori S (eds) Plant biology for cultural heritage: biodeterioration and conservation. Getty Publications, Los Angeles, pp 309-346

Chen J, Blume HP, Beyer L (2000) Weathering of rocks induced by lichen colonization. Catena 39:121-146

Clauzade G, Roux C (1985) Likenoj de Okcidenta Europo, ilustrita determinlibro. Bull Soc Bot Centre-Ouest 7:3-893

Crispim CA, Gaylarde CC (2005) Cyanobacteria and biodeterioration of cultural heritage: a review. Microb Ecol 49:1-9

Danin A (1985) Palaeoclimates in Israel: evidence from weathering patterns of stones in and near archaeological sites. Bull Am Sch Orient Res 259:33-43

Danin A (1992) Pitting of calcareous rocks by organisms under terrestrial conditions. Isr J Earth Sci 41:201-207

Danin A, Caneva G (1990) Deterioration of limestone walls in Jerusalem and marble monuments in Rome caused by cyanobacteria and cyanophilous lichens. Int Biodeterior 26:397-417

Danin A, Gerson R, Marton K, Garty J (1982) Patterns of limestone and dolomite weathering by lichens and blue-green algae and their palaeoclimatic significance. Palaeogeogr Palaeoclimatol Palaeoecol 37:221-233

de los Ríos A, Cámara B, del Cura MÁG, Rico VJ, Galván V, Ascaso C (2009) Deteriorating effects of lichen and microbial colonization of carbonate building rocks in the Romanesque churches of Segovia (Spain). Sci Total Environ 407:1123-1134

Favero-Longo SE, Castelli D, Salvadori O, Belluso E, Piervittori R (2005) Pedogenetic action of the lichens Lecidea atrobrunnea, 
Rhizocarpon geographicum gr. and Sporastatia testudinea on serpentinized ultramafic rocks in an alpine environment. Int Biodeterior Biodegrad 56:17-27

Favero-Longo SE, Borghi A, Tretiach M, Piervittori R (2009) In vitro receptivity of carbonate rocks to endolithic lichen-forming aposymbionts. Myc Res 113:1216-1227

Favero-Longo SE, Gazzano C, Girlanda M, Castelli D, Tretiach M, Baiocchi C, Piervittori R (2011) Physical and chemical deterioration of silicate and carbonate rocks by meristematic microcolonial fungi and endolithic lichens (Chaetothyriomycetidae). Geomicrobiol J 28: $732-744$

Favero-Longo SE, Benesperi R, Bertuzzi S, Bianchi E, Buffa G, Giordani P, Loppi S, Malaspina P, Matteucci E, Paoli L, Ravera S, Roccardi A, Segimiro A, Vannini A (2017) Species-and site-specific efficacy of commercial biocides and application solvents against lichens. Int Biodeterior Biodegrad 123:127-137

Gadd GM (2017) Geomicrobiology of the built environment. Nat Microbiol 2:16275

Gadd GM, Dyer TD (2017) Bioprotection of the built environment and cultural heritage. Microb Biotechnol 10:1152-1156

Garty J (1999) Lithobionts in the eastern Mediterranean. In: Seckbach J (ed) Enigmatic microorganisms and life in extreme environments. Springer, Dordrecht, pp 255-276

Gazzano C, Favero-Longo SE, Matteucci E, Castelli D, Piervittori R (2007) Allestimento di una collezione licheno-petrografica presso l'Erbario Crittogamico di Torino per lo studio del biodeterioramento di rocce e materiali lapidei. In: Proceedings of "Lo Stato Dell'arte 5: V Congresso Nazionale IGIIC; Cremona, 11-13 Ottobre 2007". Nardini, Firenze, pp 669-677

Ghadban SS, Ashhab M (2011) Stone restoration practice in Palestinian territories: a case study from Jerusalem. J Archit Conserv 17:75-96

Giordani P, Matteucci E, Redana M, Ferrarese A, Isocrono D (2014) Unsustainable cattle load in alpine pastures alters the diversity and the composition of lichen functional groups for nitrogen requirement. Fungal Ecol 9:69-72

Guillitte O (1995) Bioreceptivity: a new concept for building ecology studies. Sci Total Environ 167:215-220

Honegger R (2012) The symbiotic phenotype of lichen-forming ascomycetes and their endo-and epibionts. In: Hock B (ed) Fungal associations. The Mycota IX, 2nd edn. Springer, Berlin, pp 287-339

Jurado V, Miller AZ, Cuezva S, Fernandez-Cortes A, Benavente D, Rogerio-Candelera MA, Reyes J, Cañaveras JC, Sanchez-Moral S, Saiz-Jimenez C (2014) Recolonization of mortars by endolithic organisms on the walls of San Roque church in Campeche (Mexico): a case of tertiary bioreceptivity. Constr Build Mater 53:348-359

Kidron GJ, Temina M (2008) The mycobiont role in crustose lichen expansion on cobbles in the Negev Desert. Geomicrobiol J 25:95-100

Kidron GJ, Temina M (2013) The effect of dew and fog on lithic lichens along an altitudinal gradient in the Negev Desert. Geomicrobiol J 30:281-290

Kidron GJ, Kronenfeld R, Starinsky A (2016) Wind as a cooling agent: substrate temperatures are responsible for variable lithobiontinduced weathering patterns on west-and east-facing limestone bedrock of the Negev. Earth Surf Process Landf 41:2078-2084

Kottek M, Grieser J, Beck C, Rudolf B, Rubel F (2006) World map of the Köppen-Geiger climate classification updated. Meteorol Z 15:259-263

Lakatos M (2011) Lichens and bryophytes: habitats and species. In: Lüttge U, Beck E, Bartels D (eds) Plant desiccation tolerance. Springer, Berlin, pp 65-87

MiBACT - Italian Ministry of Cultural heritage and Activities and Tourism (2014) Linee Guida Applicative dell'articolo 182 del Codice dei Beni Culturali e del Paesaggio di cui al decreto legislativo 22 gennaio 2004, n. 42 e ss.mm.ii, pp. 1-19

Mihajlovski A, Seyer D, Benamara H, Bousta F, Di Martino P (2015) An overview of techniques for the characterization and quantification of microbial colonization on stone monuments. Ann Microbiol 65: $1243-1255$

Miller AZ, Dionísio A, Laiz L, Macedo MF, Saiz-Jimenez C (2009) The influence of inherent properties of building limestones on their bioreceptivity to phototrophic microorganisms. Ann Microbiol 59: 705-713

Morando M, Wilhelm K, Matteucci E, Martire L, Piervittori R, Viles HA, Favero-Longo SE (2017) The influence of structural organization of epilithic and endolithic lichens on limestone weathering. Earth Surf Proc Land 42:1666-1679

Nascimbene J, Salvadori O (2008) Lichen recolonization on restored calcareous statues of three venetian villas. Int Biodeterior Biodegrad 62:313-318

Nimis PL (2016) The lichens of Italy. A second annotated catalogue. EUT Edizioni Università di Trieste

Nimis PL, Seaward MRD, Arino X, Barreno E (1998) Lichen-induced chromatic changes on monuments: a case-study on the Roman amphitheater of Italica (S. Spain). Plant Biosyst 132:53-61

Pinheiro AC, Mesquita N, Trovão J, Soares F, Tiago I, Coelho C, Paiva de Carvalho H, Gilb F, Catarino L, Piñar G, Portugal A (2018) Limestone biodeterioration: a review on the Portuguese cultural heritage scenario. J Cult Herit in press. https://doi.org/10.1016/j.culher. 2018.07.008

Pinna D (2017) Coping with biological growth on stone heritage objects: methods, products, applications, and perspectives. Apple Academic Press, Oakville

Pinna D, Salvadori O, Tretiach M (1998) An anatomical investigation of calcicolous endolithic lichens from the Trieste karst (NE Italy). Plant Biosyst 132:183-195

Podani J, Schmera D (2011) A new conceptual and methodological framework for exploring and explaining pattern in presenceabsence data. Oikos 120:1625-1638

Rabinovich R, Ginat H, Schudack M, Schudack U, Ashckenazi-Polivoda S, Rogolsky G (2014) A late cretaceous elasmosaurid of the Tethys Sea margins (southern Negev, Israel) and its palaeogeographic reconstruction. Neth J Geosci 94:73-86

Salvadori O, Casanova-Municchia A (2016) The role of fungi and lichens in the biodeterioration of stone monuments. Open Conf Proc J 7(Suppl. 1 M4):39e54

Sardini P, Siitari-Kauppi M, Beaufirt D, Hellmuth KH (2006) On the connected porosity of mineral aggregates in crystalline rocks. Am Min 91:1068-1080

Seaward MRD (2015) Lichens as agents of biodeterioration. In: Upreti DK, Divakar PK, Shukla V, Bajpai R (eds) Recent advances in lichenology. Modern methods and approaches in biomonitoring and bioprospection, vol 1. Springer, New Delhi, pp 189-211

Smith CW, Aptroot A, Coppins BJ, Fletcher A, Gilbert OL, James PW, Wolseley PA (2009) Lichens of Great Britain and Ireland. British Lichen Society, London

Sohrabi M, Favero-Longo SE, Pérez-Ortega S, Ascaso C, Haghighat Z, Talebian MH, Hamid Fadaei H, de los Ríos A (2017) Lichen colonization and associated deterioration processes in Pasargadae, UNESCO world heritage site, Iran. Int Biodeterior Biodegrad 117: $171-182$

Sterflinger K (2010) Fungi: their role in deterioration of cultural heritage. Fungal Biol Rev 24:47-55

Tiano P (2016) Biodeterioration of stone monuments a worldwide issue. Open Conf Proc J 7(Suppl. 1 M3:29-38

Tonon C, Favero-Longo SE, Matteucci E, Piervittori R, Croveri P, Appolonia L, Meirano V, Serino M, Elia D (2019) Microenvironmental features drive the distribution of lichens in the house of the ancient hunt, Pompeii, Italy. Int Biodeterior Biodegrad 136:71-81

Tretiach M, Bertuzzi S, Candotto Carniel F (2012) Heat shock treatments: a new safe approach against lichen growth on outdoor stone surfaces. Environ Sci Technol 46:6851-6859 
Vella HCR (2017) Bethany in early Christian times. In: Cassar E (ed) Who was saint Lazarus? Lulu Press, Malta, pp 9-22

Warscheid T (2003) The evaluation of biodeterioration processes on cultural objects and approaches for their effective control. In: Koestler RJ, Charola AE, Nieto-Fernandez FE (eds) Art, biology and conservation. Biodeterioration of works of art. The Metropolitan Museum of Art, New York, pp 14-27
Wierzchos J, de los Ríos A, Ascaso C (2012) Microorganisms in desert rocks: the edge of life on earth. Int Microbiol 15:171-181

Publisher's note Springer Nature remains neutral with regard to jurisdictional claims in published maps and institutional affiliations. 